\title{
THE HISTORY OF ASSOCIATIONISM AND BRITISH MEDICAL PSYCHOLOGY
}

by

\section{ROBERT HOELDTKE}

Ar the beginning of the eighteenth century the time-honoured identification of mental disease with derangements of the humoral factors still prevailed. Another closely related, but less well known tradition localized diseases of the mind to specific mental faculties. Diseases of the imagination were thus distinct from diseases of the judgment, memory, or will. These ideas were based upon an implicit vitalism; i.e. the faculties were envisioned as free and active aspects of the mind in some way independent of the laws governing the material and biological world.

Faculty psychology and its assumed vitalism are of particular importance to the present study since it was this school of thought that the eighteenth century psychology of associations attempted to discredit. The complex history of this new approach is described in Warren's History of Associationism. Several distinct themes are present, the first and most fundamental element being John Locke's assertion that knowledge was based upon sensation. David Hume further developed this simple statement in his observation that the sensation of related objects became associated in the mind so that the subsequent sensation of only one of the related objects would bring about the recollection of the whole series. Finally Hartley explained associating sensation in terms of the Newtonian concepts of vibration and gravitation. In so doing he emphasized the materialistic flavour of the psychology, making it acceptable to the new science of physics, although still finding it possible to evade the charge of materialism. Despite this pious and ambivalent concession to the past, Hartley's thought represented a radical departure from the psychology of active faculties, which gradually became discredited by eighteenth-century physicians. In its place a different concept of mental disease was fashioned around the new psychology of associations. This mechanistic psychology dominated the scene for only a limited period, for in the nineteenth century interest revived in the active functions of the mind among a group of little-known Scottish physicians and psychologists. The renewed interest in faculty psychology led to a reinterpretation of associationism which was to leave a lasting imprint on modern medical psychology.

ASSOCIATIONISM AND INSANITY

John Locke first described disorders of the mind in terms of the sensing and associating mechanisms. His basic formulation was very simple-madmen associate ideas incorrectly, whereas idiots were incapable of associating ideas.

In fine, The defect in Naturals, seems to proceed from want of quickness, activity, and motion, in the intellectual Faculties, whereby they are deprived of Reason: whereas mad Men, on the other side, seem to suffer by the other Extream. For they do not appear to me to have lost the Faculty of Reasoning: but having joined together some ideas very wrongly they mistake them for Truths .... as though incoherent Ideas have been cemented together so powerfully as to 


\section{The History of Associationism}

remain united. But there are degrees of Madness, as of Folly; the disorderly jumbling ideas together, is in some more, and some less. In short herein seems to lie the difference between Idiots and Madmen. That Madmen put wrong ideas together, and so make wrong Propositions, but argue and reason right from them: But Idiots make very few or no Propositions, but argue and reason scarce at all. ${ }^{1}$

As Locke spoke of 'wrong ideas' he often implied that madness was a disease of ideas rather than a disease of men. Although Locke claimed that the proper function of reason was to associate ideas in a rational fashion, he was more impressed by the peculiar tendency of thoughts to arrange themselves in strange patterns.

Some of our Ideas have a natural Correspondence and Connexion one with another . . . Besides this there is another Connexion of Ideas wholly owing to Chance or Custom, Ideas that in themselves are not at all of kin, come to be so united in some Mens Minds, that 'tis very hard to separate them, they always keep in company, and one no sooner at any time comes into the Understanding but its Associate appears with it; and if there are more than two that are thus united, the whole gang always shew themselves inseparable. ${ }^{2}$

Locke implied in his description of the thought patterns as 'inseparable', that the association process was an automatic affair, taking place beyond the control of the active mind. Reason, though seemingly in control of thought arrangements, was helpless once the diseased pattern was established in the mind. The diseased association had the power of disrupting man's morality and behaviour, until eventually all aspects of his nature became distorted. The detrimental effects of a distorted complex of thoughts are described as follows:

This wrong Connexion in our Minds of Ideas in themselves, loose and independent one of another has such an influence, and is of so great force to set us awry in our Actions, as well Moral as Natural, Passions, Reasonings, and Notions themselves, that perhaps there is not any one thing that deserves more to be looked after ... When this Combination is settled and Whilst it lasts, it is not in the power of Reason to help us, and relieve us from the effects of it.?

David Hartley was primarily interested in defining his own concepts of vibration and association, but practical application of his psychology had an important effect on medical thought. Melancholy for instance could arise from hyper-irritability of the medullary substance, predisposing to painful vibrations." Intoxication, likewise, favoured abnormal movements in the brain. Madness was a nervous disorder resulting from the unnatural associations produced by excessive, prolonged vibrations.

Suppose a person, whose nervous system is disordered, to turn his Thoughts accidentally to some barely possible Good or Evil. If the nervous disorder should fall in with this, it increases the Vibrations belonging to its Ideas so much, as to give it a Reality, a Connexion with Self. For we distinguish the Recollection and Anticipation of things relating to ourselves, from those relating to other Persons, chiefly by the Difference of Strength in the Vibrations, and in their Coalescences with each other ... If an opposite State of Body and Mind can be introduced early, before the unnatural Associations are too much cemented, the madness is cured: if otherwise, it will remain, tho' the bodily and mental Cause should be at last removed.'

1 LOCKE, An essay on human understanding, p. 140.

op. cit., p. 420

op. cit., p. 422.

DAVID HARTLEY, Observations on man, his frame, his duty and his expectation, p. 399.

s Ibid., p. 402. 


\section{R. Hoeldtke}

Hartley's description of madness was this very similar to that of Locke, but differed in its more physiological, organic emphasis.

The initial formulations of association psychology were not readily accepted. Early eighteenth-century physicians could not easily accept the whole complex scheme of this new school of thought, for they could understand neither Locke's abstract psychology, nor Hartley's bizarre vibrational theory. Gradually, however, various elements of the new psychology found their way into medical writing; for instance in Charles Perry's discussion of madness we find little understanding of associationism, ${ }^{6}$ his theory being based upon the doctrine of animal spirits and the ancient humoral theory. Perry was none the less impressed by the claim that madness resulted from abnormal vibrations, and even went so far as to describe Hartley 'as the great champion of the world'.7 Cheyne, despite his preoccupation with faculty psychology and metaphysics, wrote extensively on the vibrating particles responsible for the nervous impulse, ${ }^{8}$ which he attempted to identify with the animal spirits. ${ }^{9}$ William Battie had no greater understanding of the basic tenets of association psychology, yet his view of madness as a disease of sensation showed the influence of Locke. ${ }^{10}$ In general, however, only fragments of the new psychology are encountered in the writings of the first half of the century. Hartley's Observations on Man, His Frame, His Duty and His Expectation was first published in 1730, but it was not until the second half of the century that his ideas were taken seriously by the medical profession. This must partly be attributed to William Cullen's adoption of Hartley's basic assumptions ${ }^{11}$ save only the vibrational theory. In a similar fashion Cullen's views on psychiatric illness were completely in accord with association psychology. ${ }^{12} \mathrm{He}$ believed that insanity was primarily a disease of the faculty of judgment. Even here faulty associations were taking place and were responsible for the disrupted judgment. Cullen described the importance of the normal and abnormal processes of association for the judging faculty as follows:

Another circumstance, commonly attending delirium, is a very unusual association of ideas. As, with respect to most of the events of common life, the ideas laid up in the memory are, in most men associated in the same manner; so a very unusual association, in any individual must prevent his forming the ordinary judgment of those relations which are the most common foundation of association in the memory, and, therefore, the usual and commonly hurried association of ideas, usually is and may be considered part of delirium. In particular, it may be considered as a certain mark of the general morbid affection of the intellectual organs. ${ }^{13}$

The view that an abnormal chain of ideas was indicative of brain disease came to be the most important and fundamental expression of associationism in medicine. Although Cullen accepted the fundamental tenets of the new psychology, he was more interested in the physiology of nerve function than in the more philosophical aspects of associationism. Nevertheless his publications stimulated further study, and several

- Charles Perry, A mechanical account and explication of the hysteric passion, p. 101.

"loc. cit.,

8 CHEYNE, English malady, p. 48.

Ibid., p. 50.

${ }^{10}$ BATTIE, Treatise on madness, pp. 35-45.

11 Cullen, Materia Medica, Vol. I, pp. 60-66.

12 CuLlen, Practice of Physic, Vol. II, p. 140.

13 Ibid, p. 142. 


\section{The History of Associationism}

books were published that both focused upon psychiatric matters and made associationism central to their approach.

Thomas Arnold's Observations on Insanity, published in 1782, explicitly attempted to utilize the concepts of contemporary psychology. Much in line with this new school, he began his treatise with a rejection of faculty psychology. ${ }^{14}$ This is remarkable since Arnold made an extensive and detailed compilation of the ways in which the faculties were used in ancient and renaissance medicine. But in so doing he was merely defining that which he intended to deny. Arnold then turned to Locke and Hartley and used their psychology as the basis of his theory. Arnold's classification of knowledge into its two main types was based upon Locke's division of knowledge into its two sources, sensation and reflection. Since there were two sources of knowledge, it followed that there were two types of mental disorders. A derangement in sensation, the source of ideas, was 'ideal delirium', while a derangement in the process of reflection was 'notional delirium' ${ }^{15}$ Arnold turned to Hartley when defining the nature of this 'notional delirium'. Since associationism is employed more explicitly by Arnold's work than by any other medical writer of the period, a summary of his theory will be quoted in full:

The mind can deduce from its perceptions and experience such relations and qualities, as are properly called notions; and are accompanied with corresponding vibrations derived from and compounded of the various sensible vibrations to which they relate; and are apt to recur to the mind in certain and regular trains, according to the order of the sensible, and notional vibrations, with which they are associated and combined. When these ideal and notional vibrations occur to the mind in their natural order, and retain their original, natural rational associations and the mind can retard or accelerate, their progress, to a certain degree, at pleasure, and can deliberately consider them and compare the past with the present, when of course, memory holds her seat, connecting consciousness, as Hartley terms it, is unimpaired and the associationism of truth and decency and propriety, and virtue remain uninjured; in short when the mind can regulate properly all its operations, it is then a sound and rational state: but in proportion as the reverse takes place, in such proportion is it in a state of unsoundness and insanity. When such an interruption in the regular course of the vibration of the brain, and of the right operations of the mind, may be produced by each of the variations, above enumerated of the proximate causes of insanity. ${ }^{16}$

The quotation shows that Arnold's thought was not limited by the fact that he made association psychology central to his theory. A wide variety of influences, both bodily and mental, could alter the natural succession of vibrations; overactivity of the arteries, venous congestion, or organic changes in the texture of the brain could directly alter the vibrations, ${ }^{17}$ as could psychological factors, such as prolonged study or sudden passions. ${ }^{18}$ The interactions of the mind and the body could thus be readily explained by the mechanistic psychology of associations.

Arnold's work was significant because it incorporated many basic elements of eighteenth-century philosophy. Sensation was the basis of sanity, as well as of knowledge. The mind, though immaterial, operated according to mechanical laws. Most importantly for our purpose, insanity became identified with abnormal association patterns. In general, few of the physicians of the period made such a comprehensive

\footnotetext{
14 ARnold, Observations on insanity, Vol. I, p. 59.

18 loc. cit.

10 lbid., Vol. II, p. 284.

17 Ibid., Vol. II, p. 287.

18 Ibid., Vol. II, pp. 161-87.
} 


\section{R. Hoeldtke}

use of association psychology as did Arnold. But even those physicians who displayed no great knowledge of academic concepts of the mind, often described in detail the 'morbid train of thought' or the 'perverse association' of their psychiatric patients. Andrew Harper, for example, noted the common tendency for a fixed 'connexion of ideas' to perpetually recur throughout a patient's course. ${ }^{19}$ William Falconer spoke of the disposition of the mind to combine ideas in a fixed pattern as a "basic canon of the human constitution'. ${ }^{20} \mathrm{He}$ applied this theory to a medical situation by the following simple but appropriate example:

The power of association of ideas in the mind is here very remarkable. A child was frightened into an epileptic paroxysm by fear, induced by a great dog leaping upon him. The fit returned upon his seeing some time afterwards a larger dog than the one which had caused his terror, and even by hearing his barking at a distance. ${ }^{31}$

Francis Willis, too, was particularly impressed by Cullen's work, and regarded mental disorder as nervous disease that resulted, inter alia, in a decreased ability to properly connect ideas. ${ }^{22}$ In a few rare instances the doctrine crept into the neurological writings. Erasmus Darwin, for example, devoted a large part of his primitive neuropathology to those diseases in which the 'association' of various nervous tissue mechanisms was disrupted. ${ }^{23}$ These sundry uses of associationism are important in that they illustrate the extent to which the concept had infiltrated eighteenthcentury medicine. What is most impressive is the specific use of association psychology by those few physicians who were both philosophers and psychiatrists.

Alexander Crichton was the first physician after Arnold to fulfil both these criteria. He was, perhaps, more thoroughly familiar with the philosophical writings of his day than any other contemporary physician. The influence of these academic influences on his psychiatric thought can be seen in his nosological classification. Three basic types of mental derangement were postulated. The first was delirium, in which both perception and the higher faculties were deranged. Illusion formed the second category, in which perception was diseased while the higher faculties remained intact. In the third class of illness, amentia, the faculties were deranged independent of perception. ${ }^{24}$ Diseases of the associating mechanism fell into this third class, for Crichton regarded the association of mental data as the mechanism by which the various intellectual faculties operated. If the process of association was unusually strong, the imagination and memory would be so lively as to override the power of judgment to rearrange the thought combination..$^{25}$ If the associating powers were too weak, the memory and imagination would suffer and a dull intellect would result. ${ }^{26}$ For these reasons, Crichton felt that memory, judgment and imagination were the faculties most closely dependent upon proper association. It followed that these were the faculties to become diseases when the associating powers became distorted.

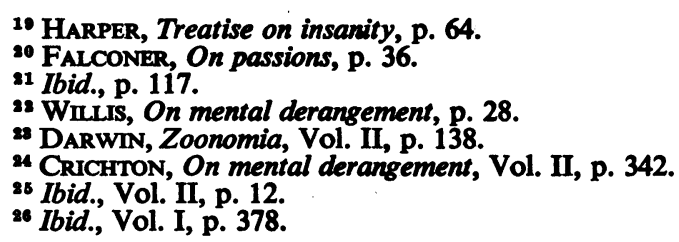




\section{The History of Associationism}

As the insane idea generally consists in certain combinations of thought which experience does not yield, but are formed in the mind, either by feelings or strong passions and desires, this malady appears to belong to the imagination. Although we are indebted to the principle of association of ideas, yet it often becomes the source of much misery and distress, as well as of many false judgments. ${ }^{27}$

Crichton's use of association psychology was more complicated than that of Arnold, and was a result of Condillac's influence on his thoughts. ${ }^{28}$ Condillac, whilst fully accepting the fundamental tenets of associationism differed from his English contemporaries in retaining the traditional view that the faculties were distinct aspects of the mind. Crichton, in following his example, developed a nosology based upon diseases of specific faculties. To complicate matters, Crichton was also influenced by the Scottish school of philosophy founded by Thomas Reid, being impressed by the dogmatic insistence that the mind was immaterial. ${ }^{29}$ It followed that Hartley's vibrational theory, or any similar physical mechanism for thought, had to be rejected. which meant that only mental data, and not motions in the brain, were associated.

Crichton's knowledge of philosophy made it possible for him to adopt selected elements from very diverse sources. This eclectic approach had some virtue since, as with Arnold, it left room for the mental as well as the physical. Since Crichton adopted Condillac's view that the higher faculties were dependent upon sensation, mental derangement could arise from any condition affecting the sensing process. It thus became possible to explain insanity resulting from purely bodily factors, such as heat, fever, or tumours of the nerves. But since, as the Scottish metaphysicians maintained, the mind was free and active, it could become deranged of its own accord. Such was the case in those primary diseases of the intellectual faculties occasioned by a distorted association process. Crichton's eclectic approach was flexible and comprehensive but his work, in general, lacked consistency. The view that the faculties resulted from interacting sensations could never be reconciled with his reactionary insistence upon the immateriality of the soul. Hartley, Cullen, and Arnold paid lip-service to traditional themes, but Crichton took more seriously the claim that the mind could exist independently of matter. As a result, the inconsistencies latent in the psychiatric writings of the period became manifest in his writings.

Both the virtues and the ambiguities of Crichton's eclecticism dissolved in the writings of John Haslam. In his work the basic problem of previous psychiatric thought was the lingering belief in the immateriality of the soul, a belief that could not be reconciled with the new empiricism in science and philosophy. Haslam took what he considered to be the obvious and logical step. He rejected the soul, and with it, all the traditional views of the faculties. After briefly describing the classical attempts to divide the mind into its separate powers, Haslam gave his own views of the faculties as follows:

... (psychologists) appear to be generally agreed, that the human mind possesses certain faculties and powers; as imagination, judgment, reason, and memory ... As far as I have observed respecting the human mind, it does not possess all those powers and faculties with which the pride of man has thought proper to invest it.80

$$
\begin{aligned}
& \text { "I Ibid., Vol. I, p. } 382 \text {. } 23 \text { Ibid., Vol. I, p. } 378 . \\
& \text { "9 Ibid., Vol. I, pp. } 220-48 . \\
& \text { 30 HASLAM, Madness and melancholy, p. } 8 .
\end{aligned}
$$




\section{R. Hoeldtke}

To justify this view, Haslam had to utilize nearly all the elements of the eighteenth-century psychology we have been discussing. He did this in a unique fashion, and couched his argument in terms of a novel etymological argument. $\mathrm{He}$ believed that the language of the faculty psychologists was not the product of free and independent minds, but was derived from perceptible objects in the physical world. 'Sorrow', a term for a mental feeling, was borrowed from 'soreness', a well known state of the body. Conception, derived from 'cum' and 'capio' brought to the mind the physical notion of 'grasping together' or embracing. Perception was derived from 'per' and 'capio' naturally meant to 'grasp through' the organs of sense. Thus these psychological terms were based upon subtle relationships with objects and activities of the real world. Since the mind was not capable of formulating a language independent of the external world, then the mind was not independent. Haslam summarized this argument as follows:

If mind were actually capable of the operations attributed to it, and possessed these powers, it would necessarily have been able to create a language expressive of these powers and operations. But the fact is otherwise. The language which characterizes mind and its operations has been borrowed from external objects."

From these assumptions it followed that the faculties themselves, like the language of mind generally, were dependent upon those physical objects upon which their etymology was based.

It can scarcely be necessary, to fatigue the reader, by reverting to the etymology of those terms which have been considered as significant of mind and its operations. Everyone will be able sufficiently to develop imagination, reflection, combination (as applied to ideas, importing the amalgamation of two into one) abstraction ... . and a variety of others; and to show that they have arisen from physical objects and the circumstances which surround us, and are independent of any operation which mind has eleborated.92

The above argument, however bizarre at face value, is but a novel formulation of the empirical psychology with which we are already familiar. Haslam's thesis can be reduced to the simple syllogism: Since the mind depended upon language, and language depended upon the external world, it followed that the mind also depended upon the external world.

The etymological argument was only one approach among many. Haslam also had several less abstruse reasons for rejecting the faculties. The one most pertinent here depended upon a straightforward application of association psychology. Haslam compared the innate intellectual abilities of young animals and human infants. Young beasts, it was argued, developed more quickly than young children, and also possessed greater powers of memory. Thus any superiorities that appeared in human adulthood could hardly be attributed to higher innate powers. It was, rather, the distinctively human capacity to form a language which made possible those associations and perceptions that provided the foundation of intelligence. ${ }^{33}$ Since the sensing and associating mechanisms were the basis of language, then they were also the basis of thought. The adoption of this approach, along with the rejection of the faculties, was a logical extension of Locke's ideas concerning sensation, a fact that Haslam

21 Ibid., p. 9 . 22 Ibid., p. 15. 


\section{The History of Associationism}

readily acknowledged. This dependence upon Locke is an important feature in Haslam's thought, and can also be seen in the adoption of his predecessor's belief that the perversion of natural association was a characteristic feature of the insane. Haslam even claimed that the 'proper succession' of ideas was the most important single factor upon which the health of the mind depended. ${ }^{34}$ Haslam went further than Locke and argued that the association process, normal or abnormal, took place passively within the physical substance of the brain. The organic basis of the association process had already been stated by Hartley, Cullen and Arnold, but Haslam was more explicit than his predecessors. He summarized his brain-oriented approach to the mind as follows:

Perhaps it is not more difficult to suppose that matter, peculiarly arranged, may think, than to conceive the union of an immaterial being with a corporeal substance. It is questioning the infinite wisdom and power of the Deity to say that he does not or cannot arrange matter so that it shall think. We found insanity, as far as has been hitherto observed, uniformly accompanied with disease of the brain, is it not more just to conclude, that such organic affection had produced this incorrect association of ideas."3

Haslam's materialism, in both philosophical and psychiatric matters was much less equivocal than its eighteenth-century variant. In summary, Haslam's thought is refreshingly straightforward. It provided a consistent resolution to the many conflicting elements found in previous works. Haslam vehemently castigated the ambivalence and vacillation of his predecessors. To do so, he had to weld together many elements of eighteenth-century psychology. The proper functioning of the mind depended upon language, and the latter, in turn, depended upon the materialistic process of associating sensations. Upon this basis faculty psychology, and the scholastic metaphysics that was often linked to it, were clearly rejected. Haslam thus represents the proper culmination of that school of philosopher-physicians stemming from Locke and Hartley.

\section{NEW ELEMENTS AND THE DECLINE OF ASSOCIATIONISM}

Although a large number of books on psychiatric subjects appeared during the first decades of the nineteenth century, few made more than passing references to the association of ideas. Joseph Cox, in his Practical Observations on Insanity, described the common tendency of the mind to 'rivet its attention' to one train of thought. There is an obvious similarity between his simple descriptive approach and the more abstract philosophical works already discussed. This can be seen in the following excerpt from Cox's work:

Whatever agitates the mind intensely, whatever occupies it exclusively, always hazards its faculties, inducing a state favourable to the attack of mental disease. Riveted attention to one train of thought, is a very frequent source of insanity; the first effects of this dangerous practice are obvious in the loss ... of volition, in an inability to abstract the mind from the subject, which so interests and, occupies it ... It is a curious fact, that a peculiarity somewhat analogous attaches to the sense of hearing, sight, and feeling; whatever has occupied either of them for a considerable length of time, will seem to be present long after it is dismissed; thus the sense of motion after sailing, the perpetual recurrence of tunes, etc."se

a Hastam, Observations on madness, p. 34.

${ }^{35}$ HAsL AM, Madness and melancholy, p. 240.

"Cox, Practical Observations on insanity, p. 15. 


\section{R. Hoeldtke}

Cox's allusion to the persistence of sensation after the removal of the eliciting stimulus is of particular interest. The persistence of mental data in the mind was a fundamental assumption upon which association psychology was based. It is remarkable that Cox should make this traditional and sophisticated analogy in a basically simple and practical treatise which was almost devoid of references to academic psychology.

Other uses of associationism were not so subtle. In Allen's Essay of Classification it is suggested that mental hospitals should have several buildings, each of distinct style and appearance, in order that patients, upon improving, could be moved into different quarters. It was assumed that during the worst phase of an illness the patients developed 'painful associations' with objects in the immediate environment, which could be broken merely by placing the ill person in a new building. ${ }^{37}$ Allen asserted, in a similar fashion, that patients were not advised to leave the institutions since 'painful and dangerous association', of which the patient might not even be aware, were commonly attached to homes and families. ${ }^{38}$

A wealth of such practical applications of and superficial allusions to 'associated ideas' can be found in the psychiatric writings of Haslam's time. The many references to the 'morbid train of thoughts' indicate that the concept of associations was not merely the preoccupation of the philosophers. Strange or incoherent thought patterns were thought to be a fundamental characteristic of the mentally ill.

Association psychology, as a school of thought, ceased to play a significant role in the English writings of the early nineteenth century. Haslam greatly influenced the physicians of his day, although they were more impressed by his organic approach than by the eighteenth-century psychology upon which it was based. They were less interested in mental phenomena than in physiology and pathology of the brain. Spurzheim referred to Haslam as the source of his belief that mental disease would be a mystery until the functions of the brain were understood. ${ }^{39}$ It was the materialistic assumptions of the new science of phrenology that accounted for much of its appeal. William Lawrence, in a typical fashion, found it hard to accept the phrenologists' specific views on the functions of the brain, but nevertheless welcomed the new 'science' since it properly assumed a material basis for thought. ${ }^{40}$

Another sequel to Haslam's brain-oriented approach was the development of neuropathology. Haslam himself carried out dissections on the brains of the insane, as did Lawrence, ${ }^{41}$ Crowther, ${ }^{42}$ Burrows, ${ }^{43}$ and numerous French physicians. It was hoped that the pathological appearance of the brain would provide a new method for classifying insanity. Burrows dogmatically stated that this new approach precluded the psychological classifications of the preceding century.44

Burrow's rejection of the academic approach of the eighteenth-century psychologists was a common tendency observed among other nineteenth-century writers. John Mayo, in his treatise On Insanity, rejected the nosologies of Arnold and Crichton as

\footnotetext{
${ }^{87}$ Allen, On insanity, p. $3 \quad{ }^{88}$ Ibid., p. 97.

SPURZHEIM, Observations on the deranged manifestations of the mind, pp. 7, 67.

40 LAWRENCE, Lectures on physiology, zoology and the natural history of man, p. 200.

11 Ibid., p. 99.

4 CrowTHER, Insanity, title page.

is BuRROWs, Insanity, p. 67.

4 Ibid., p. 251.
} 


\section{The History of Associationism}

'too psychological'. ${ }^{45}$ The study of insanity was the study of the brain, and psychology had no function but to retard progress. ${ }^{46}$ In a similar fashion David Uwins rejected the psychological distinctions of Arnold because they did not conform with clinical observations. ${ }^{47}$ Uwins regarded Haslam as the great authority of the day on psychiatric matters, but criticized him for being 'a little too philosophical'. ${ }^{48}$ Spurzheim did not even discuss the views of Locke and Arnold. 'They are of no practical use and I shall not intrude upon the time of my readers with their consideration.'49

It is remarkable that eighteenth-century psychology, commonly thought of in its own day as progressive and empirical, was considered speculative and metaphysical in the following century. Those few physicians of the period who retained an interest in the purely mental looked to Pinel and the French school rather than to their English predecessors. The French belief that the moral sense could be deranged in the absence of intellectual disease was discussed in many psychiatric works, especially those of William Neville ${ }^{50}$ and Edward Seymour, ${ }^{51}$ This concept also greatly influenced the development of medical jurisprudence through the efforts of James Prichard. Other writers of the period spoke of the moral (as opposed to the physical) causes of insanity, an idea closely related to the development of the non-restraint movement and to moral treatment. Thus a number of diverse elements can be discerned in the English psychiatry of the early nineteenth century. The new French concepts, the primitive science of phrenology, and the pathological studies of the brain did much to occupy the attention of the physicians interested in mental diseases. These new elements, coupled with the prevalent scepticism concerning matters of the mind, left little room for the association psychology, which had been so important during the previous century.

\section{SCOTTISH REINTERPRETATION OF ASSOCIATION PSYCHOLOGY}

The rejection of association psychology by Burrows, Spurzheim, and their pragmatic colleagues did not mean that the concept of mental associations was heard of no more. The psychology of Hume and Hartley was not merely a historical curiosity whose medical use was confined to a sect of extraordinarily philosophical eighteenthcentury physicians, for it still held an appeal in academic circles. Warren has shown how James Mill adopted the basic concepts of Hume and Hartley, and applied them to political theory, law, ethics, and to a wide variety of other subjects. ${ }^{52}$ Alexander Bain, too, wrote an extensive treatise in defence of the whole doctrine of associationism which greatly impressed John Stuart Mill and Herbert Spencer. The English philosophers considered the psychology of Hume and Hartley well worth preserving, but insofar as medical psychology is concerned, the most interesting nineteenthcentury use of associationism is to be found among a little known group of Scottish psychologists and physicians.

The history of ideas often follows patterns that are more geographical than chrono-

4 Mayo, Treatise on insanity, p. 7.

16 Ibid., p. 89.

17 UWINS, $A$ treatise on the disorders of the brain and nervous system, p. 28.

48 Ibid., p. 89.

so NeVILLe, On insanity, p. 19.

51 SeYmour, Observations on medical treatment of insanity, p. 35.

s2 WARREN, History of associationism, p. 37. 


\section{R. Hoeldtke}

logical. This can be seen in the rejection of the English psychology by certain Scottish philosophers as early as the mid-eighteenth century, when the influence of Newton, Locke and Hartley was at its height. The Scottish philosopher-physician, John Gregory, opposed the mechanistic philosophy of 'the neighbouring country' and praised the 'enlarged genius' of the vitalist, George Stahl. ${ }^{63}$ At the same time, Thomas Reid formulated many of the basic assumptions of the Scottish 'common sense' school of philosophy. He disagreed with the attempts of Hume and his English colleagues to reduce intellectual activity to the physiological processes of sensation and association, for he was opposed to the way in which these mechanistic concepts neglected the soul and its innate activities. To combat a growing scepticism, Reid returned to the faculty psychology which his progressive contemporaries had rejected. It was not the biological faculties of Aristotle and Galen that interested the Scottish philosopher. In quite a different fashion Reid restated the highly metaphysical, scholastic view of the mind..$^{\text {s4 }}$ Intellectual activity was based upon innate inductive powers called faculties. The dogmatic and radical nature of Reid's thought can be seen in his reluctance to allow even perception to take place in the material world. The intellect 'sees' or the intellect 'hears' directly; i.e. these processes took place simply because God had given man the perceptive faculties. ${ }^{55}$ Reid dismissed the English belief that objects yielded impressions transmitted along the nerves and in this way pushed a dualistic interpretation of faculty psychology to its further limit, for even Aquinas had allowed the sensitive faculty to operate through bodily organs. Few of the Scottish philosophers completely accepted Reid's radical view of the faculties, although the general emphasis upon the innate power of the mind to act independently of sensation was the common denominator of Scottish philosophy. It was perhaps Scotland's conservative Presbyterianism that dictated these traditional views. Certain of Reid's followers were nevertheless interested in Hume and Hartley's associations, an interest which complicated matters considerably since associationism and faculty psychology were historically linked to very different schools of thought. A compromise of some sort was necessary and to effect this the Scottish philosophers redefined the tenets of association psychology.

Thomas Brown's writings in the early nineteenth century show a greater affinity for Hume than Reid. Brown wrote extensively on the laws of association, and with the sole exception of Hartley, he made this concept more central to his thought than any other philosopher we have discussed. His substitution of the term suggestion for association shows that Brown could never be considered an adherent of the eighteenthcentury school. The former term was considered more desirable since it left room for the participation of the mind. ${ }^{56}$ The intellect could actively respond to sensations (suggestions) by perceiving relationships with prior sensations. Such a concept was quite different from the eighteenth-century idea that associations took place automatically, i.e. the earlier school maintained that sensations (ideas) were associated simply because they preserved relationships of external objects in time and space. For the eighteenth-century psychologists the mind remained passive and did little

GREGORY, A comparative view on the state of the faculties, p. 8.

$4 \mathrm{R}$ EID, Essay on the intellectual powers of man, pp. 6-7.

ss Ibid., p. 54.

so Brown, Lectures on the philosophy of the human mind, Vol. II, p. 336. 


\section{The History of Associationism}

more than perceive. To combat these ideas, Brown claimed that sensations did not merely call forth the operation of automatic, associating laws that were dictated by the environment. Sensations acted as suggestions upon which the mind could operate by forming relationships as it saw fit. The precise role of the mind in connecting thought is more precisely delineated in Brown's distinction between simple suggestion and relative suggestion. The process of simple suggestion was nearly identical to that of association as defined in the previous century. But relative suggestion, also called the faculty of comparison, involved an active process by which relationships were established by the mind's own effort. This distinction was illustrated in the following way: The perception of an individual might be naturally associated with certain perceptions of the home, family, and clothes of that individual. These objects shared the common property of having been perceived at some prior time in connection with that individual. Such correlations might be explained upon the basis of the laws of simple suggestibility; i.e. the suggestion was derived from obvious relationships in the external world. If this individual were to possess some remarkable feature, such as an unusually great height, then the perception of him might bring about the thought of some totally distinct person with the opposite characteristic of being extremely short. ${ }^{57}$ In the latter instance, it was the mind, and not the external world, that formed the association. Since simple suggestion could not explain this second type of association, the law of relative suggestibility was necessary. In general, the latent scholastic concepts of Reid can be found in Brown's treatment of association psychology. It must be admitted that these concepts were secondary to Brown's straightforward notion of simple suggestion, which differed little from eighteenthcentury associationism. The departure from the thought of the previous century is to be found in the writings of Dugald Stewart, Brown's Scottish contemporary. Stewart's treatment of the phenomena of mental associations is quite different from that of his colleague, yet the same basic compromise prevailed. He accepted the traditional notion that perceptible objects had a tendency to awaken thoughts in the mind independent of any mental process, ${ }^{68}$ but also incorporated Reid's approach when he claimed that the associating ability of the mind was controlled by various distinct faculties. Thus the exact content of any mental association depended upon whether or not the faculty of attention was engaged. ${ }^{50}$ In a similar fashion, the mind could voluntarily alter a given train of thought by singling out one distinct element and focusing the mind upon it. ${ }^{\circ 0}$ In this way the traditional scholastic emphasis upon the freedom of the will, the highest faculty of all, was reconciled with the progressive, sceptical psychology of the eighteenth century.

Stewart wrote extensively upon the importance of the associating process for various mental disciplines. The power of the mind to arrange thoughts in new and unique combinations was seen to be the basis of humour, poetry, and science. ${ }^{61}$ In the light of later developments, the most important of Stewart's applications of associationism involved the phenomena of sleep and dreaming. The application of his theory to these phenomena is especially pertinent since it admirably demonstrates Stewart's

un Ibid., p. 342.

st STwART, Elements of the philosophy of the human mind, Vol. II, p. 252.

s. Ibid., p. 260.

11 Ibid., pp. 274-85. 


\section{R. Hoeldtke}

eclectic treatment of the associating process. The basic argument was very simple. Stewart claimed that during sleep the passive natural associations could take place without the perpetual interference of the active powers of mind. Since the will and the attention were suspended, thoughts could be connected passively after the fashion of the eighteenth-century philosophers. This meant that the dreaming state provided a valuable opportunity for examining the associating process directly. ${ }^{62}$ Since the active faculties ceased to function, the natural, involuntary associations came to the surface. Stewart summarized his application of association psychology to the phenomena of sleep and dreaming as follows:

... the same laws of association which regulate the train of our thoughts while awake, continue to operate during sleep. I now proceed to consider, how far the circumstances which discriminate dreaming from our waking thoughts, correspond with those which might be expected to result from the suspension of the will.

If the influence of the will is suspended during sleep, all our voluntary operations, such as recollection, reasoning, etc. must also be suspended.

That this really is the case, the extravagance and inconsistency of our dreams are sufficient proofs. We frequently confound together times and places the most remote of each other; and, in the course of the same dream, conceive the same person as existing in different parts of the world ... All this proves clearly, that the subjects which then occupy our thoughts, are such as present themselves to the mind spontaneously and that we have no power of employing our reason..$^{83}$

Such an interest in sleep and dreaming could never have developed in the English School of the previous century since the mind, given no active power of its own, could hardly be capable of being suspended. Stewart also described other situations in which the faculties of the mind lost control over the associating process. In somnambulism, for example, a large measure of the powers of mind were suspended so that thought was basically spontaneous and uncontrolled. The same interpretation was applied to madness:

In madness, the power of the will over the body remains undiminished, while its influence in regulating the train of thought is in a great measure suspended; either in consequence of a particular idea, which engrosses the attention, to the exclusion of everything else, and which we find it impossible to banish by our efforts; or in consequence of our thoughts succeeding each other with such rapidity, that we are unable to stop the train. ${ }^{.4}$

The above quotation appears much like the standard eighteenth-century application of association psychology, but there was a new emphasis in Stewart's thought on the power of the will to control associations. This concept came to play a major role in the psychiatric writings of the time.

\section{SCOTTISH ASSOCIATIONISM IN MEDICAL WRITINGS}

James Prichard and John Conolly were both educated in Edinburgh where they became familiar with the ideas of Brown and Stewart. Although academic questions were not the primary interest of either of these two English physicians, both made extensive reference to the psychology of mental associations in their medical writings. Prichard rejected Hartley's mechanistic views of the mind, and substituted the Scottish view that ideas could be connected actively or passively. ${ }^{65}$ Prichard quoted Stewart

\footnotetext{
os Ibid, pp. 298-305. es Ibid., p. 299.
}

os PRICHARD, $A$ review of the doctrine of a vital principle, pp. 149, 175. 


\section{The History of Associationism}

as the source of his belief that insanity involved a suspension of the active associating power. ${ }^{66}$ Stewart's influence thus produced a subtle shift from the eighteenth-century view that the associations themselves were diseased. It was rather the scholastic faculty of volition that was considered the primary site of derangement.

... the loss of voluntary power over the succession of ideas is so great in a certain period of dementia that the individual affected is incapable by any effort of mind of carrying on the series of his thoughts to the end of a sentence or proposition. ${ }^{67}$

To regard insanity as a disease of the will fitted well with Prichard's interest in forensic psychiatry, while his religious beliefs agreed with the theology that was latent in the Scottish concept of mind. This perhaps explains why Prichard broke with his sceptical English predecessors and turned to the Scottish and French schools.

John Conolly's concept of insanity was nearly identical to that of Prichard. Insane patients were described in whom the involuntary associations were so strong that ideas could no longer be connected by the will. ${ }^{68}$ In his definition of insanity Conolly claimed that the primary site of disease, was the comparing faculty, ${ }^{69}$ an idea undoubtedly derived from the Scottish school. The faculty of comparison, it will be remembered, was an important focus of discussion for the Scottish psychologists since it was generally considered equivalent to Thomas Brown's process of relative suggestibility. The psychology of Stewart and Brown also influenced Scottish physicians; John Abercrombie, for instance, considered Brown's division of association into simple and relative suggestion a fundamental concept, for associations could be classified on the basis of whether or not they were made voluntarily. ${ }^{70}$ Abercrombie further claimed that spontaneous associations could be observed in pure form in states of dreaming, somnambulism, or insanity. ${ }^{71}$ But at this point, he made the important observation that passive associations often took place in the absence of conscious awareness. ${ }^{72}$ This notion was implicit in the writings of Stewart but were not elaborated upon; Stewart did not relate the associating process to the doctrine of the conscious mind. Even Abercrombie only made this correlation in a hasty and imprecise fashion. Nevertheless the location of the associating process within the realm of subconscious mental activity came to be a very important outgrowth of Stewart's and Brown's psychology as it was developed by Sir William Hamilton and Thomas Laycock, the two most influential Scottish psychologists of the century.

\section{ASSOCIATION PSYCHOLOGY AND THE SUBCONSCIOUS MIND}

The philosophy of William Hamilton resists an easy explication. As the most erudite member of the Scottish school, Hamilton had studied medicine, law, classics, and philosophy. His learning reinforced the unique and radical nature of his thought. As a result, Hamilton was an autocratic figure among the British philosophers of the mid-nineteenth century. Even John Stuart Mill dedicated one of his works to a consideration of Hamilton's thought. In addition, Hamilton's great genius impressed the physicians, despite his neglect of the medical approach he was equipped to employ. This can be seen in Thomas Laycock's work, which, though original and

\footnotetext{
os Prichard, On insanity, p. 94.

8 CONOLLY, Indications of insanity, p. 154

${ }^{\circ}$ ABERCROMBIE, Intellectual powers, p. 96.

${ }^{11}$ Ibid., pp. 111-12.
}

or Ibid, p. 95

6 Ibid., p. 300.

${ }^{72}$ Ibid., pp. 108-111. 


\section{R. Hoeldtke}

comprehensive in its own right, was heavily indebted to his predecessor's thought. Hamilton and Laycock, both highly learned and highly influential, provided the logical culmination of their school, standing last in that line of eclectic Scottish philosophers which sprang from Hume and Reid.

Hamilton's extensive knowledge of philosophy made it possible for him to adopt ideas from very diverse sources. This is admirably demonstrated in the doctrine of subconscious mental activity. This complicated theory, in a fashion typical of Hamilton's philosophy, stemmed from several distinct and basically unrelated arguments. Hamilton presented his thesis in a highly abstract context centred around a discussion of Descartes, Leibnitz, and Locke. ${ }^{73}$ Descartes was the original proponent of the view that the mind is continually active. This was based upon one of the famous Cartesian self-evident propositions: i.e. since thought was the defining property of its underlying substance, the soul, the two concepts could never be divorced. Locke challenged this thesis in the simple observation that thought and consciousness were suspended during sleep. Leibnitz remained true to the Cartesian doctrine when he argued that thought was perpetuated in the form of dreams. Locke's claim that dreams only occurred infrequently was countered by Leibnitz's further assertion that dreams often took place beyond the level of awareness. Hamilton extended Leibnitz's argument by insisting that dreaming always accompanied sleep. This was illustrated by Leibnitz's reference to the host of feeble perceptions that occur upon waking from sleep. Hamilton dramatized Leibnitz's observation by carrying out an experiment upon himself in which he allowed himself to be awakened several times from deep sleep. In each instance, he argued, proper application of the mind revealed some fleeting thought associations barely within the limits of awareness.

... when suddenly awakened during sleep (and to ascertain the fact I have caused myself to be aroused at different seasons of the night), I have always been in the middle of a dream. The recollection of this dream was not always equally vivid. On some occasions I was able to trace it back until the train was gradually lost at a remote distance; on others, I was scarcely certain of more than the fact that I was hardly aware of more than one or two links in the chain; and sometimes was scarcely aware of more than the fact, that I was not awakened from an unconscious state ... When snatched suddenly from the twilight of our sleeping imaginations, and placed in the lustre of waking perceptions, the necessary effect is to obliterate the traces of our dreams. ${ }^{74}$

Upon these arguments Hamilton based his claim that the dreaming state, though often hidden from awareness, was a constant feature of sleep. In addition to Leibnitz, Hamilton quoted his German contemporary, Immanuel Kant, as the source of this idea. But in spite of these diverse influences Hamilton's view of dreaming was much in accord with his Scottish predecessors. The only difference was that the earlier writers, still vaguely in touch with eighteenth-century concepts, viewed dreaming as a manifestation of the passive mind of the early associationists. Hamilton, dependent upon different and more diverse schools of thought, interpreted the same phenomena in terms of consciousness.

Hamilton elaborated at great length his doctrine of subconscious mental activity. He carried his novel, radical theory much farther than might be expected. The con-

72 Hammton, Lectures on metaphysics and logic, Vol. I, pp. 310-36.

"Ibid., p. 323. 


\section{The History of Associationism}

scious, active mind, for so long the preoccupation of philosophers, was but a fraction of the total intellectual apparatus. '. . . the infinitely greater part of our spiritual treasures lies beyond the sphere of consciousness, hid in the obscure recesses of the mind.75 But in spite of the dramatic and unusual terminology, Hamilton was thoroughly in the tradition of his Scottish predecessors when he claimed that the new aspects of the mind could best be observed in certain abnormal mental states. This relation is illustrated by the following passage, in which Hamilton patterned himself after Stewart by speaking of madness, delirium, and somnambulism:

. . . the mind contains certain systems of knowledge, or certain habits of action, which it is wholly unconscious of possessing in its normal state, but which are revealed in consciousness in certain extraordinary exaltations of its powers. The evidence on this point shows that the mind frequently contains whole systems of knowledge, which, though in our normal state have faded into oblivion, may, in certain abnormal states of madness, febrile delirium, somnambulism, catalepsy, etc., flash out into luminous consciousness and even throw into the shade of unconsciousness those other systems by which they had, for a long time, been eclipsed and even extinguished. ${ }^{76}$

Hamilton did not rigidly adhere to the notion that subconscious activity was only evident in certain extraordinary states of mind. There were also consciouslyexperienced, common phenomena that fit well with the concept of a mind that existed beyond awareness. The most important of these well-known mental events was the association of several basically unrelated ideas by trains of thought that existed outside of consciousness. This observation is of extreme importance for our study, since it gave association psychology an entirely new interpretation. The following argument from Hamilton's work is included in full, since it admirably demonstrates the way in which the notion of mental associations could be linked with the doctrine of the subconscious mind.

... Suppose, for instance, that A, B, C, are three distinct thoughts-that A and C cannot immediately suggest each other, but that each is associated with $B$, so that $A$ will naturally suggest B, and B naturally suggest $C$. Now it may happen that we are conscious of A, and immediately thereafter of C. How is this anomaly to be explained? It can only be explained on the principle of latent modification. A suggests C, not immediately, but through B; but as B ... does not rise into consciousness, we are apt to consider it as non-existent. You are probably aware of the following fact in mechanics. If a number of billiard balls be placed in a straight row and touching each other, and if a ball be made to strike in the line of the row, the ball at one end of the series, what will happen? The motion of the impinging ball is not divided among the whole role; this, which we might a priori have expected, does not happen, but the impetus is transmitted through the intermediate balls which remain each in its place, to the balls at the opposite end of the series, and this ball alone is impelled on. Something like this often seems to occur in the train of thought. One idea mediately suggests another into consciousness-the suggestion passing through one or more ideas which do not themselves rise to consciousness. The awakening and awakened ideas here correspond to the ball striking and the ball struck off; while the intermediate ideas, which carry the suggestion, resemble the intermediate balls which remain moveless, but communicate the impulse. ${ }^{72}$

From its very beginning associationism was explained by reference to mechanical events of motion and interaction, and Hamilton's comparison of thought connections with colliding billiard balls fitted very well into this tradition.

Hamilton's treatment of association psychology and the subconscious mind formed only a small portion of his comprehensive philosophical writings. Large selections of
75 Ibid., p. 339.
36 loc. cit.,
"I Ibid., p. 352. 


\section{R. Hoeldtke}

his work were not original, but followed contemporary Scottish philosophical notions. He followed Brown and Stewart in attempting to reconcile Reid's dogmatic affirmation of mind and the associationists' reserved affirmation of the external world. ${ }^{78}$ But Hamilton departed from the Scottish school in accepting the Kantian emphasis upon the active Ego, important both to his theory of consciousness and to his interpretation of dreams. ${ }^{79}$ Hamilton claimed it was necessary to turn to the German philosophers since Stewart and Reid had refrained from following their psychology to its logical conclusion by correlating it with the doctrine of consciousness. ${ }^{80}$ Brett in his History of Psychology claimed that Hamilton's incorporation of German idealism was a landmark in British psychology. ${ }^{81}$ From this point onward the simple associationism of Hume and Hartley was no longer adequate.

Thomas Laycock's philosophical writings were even more comprehensive and eclectic than those of Hamilton. A thorough discussion of Laycock's thought would be a monumental task, and will not be attempted. Much of his writings were based upon distinctively nineteenth-century developments and are beyond the domain of this study. His dependence upon the German philosophers exceeded even that of Hamilton. Kant, Fichte, Schelling, and Hegel were all referred to as the source of his doctrine of consciousness. ${ }^{82}$ But Laycock differed from Hamilton in that he was more thoroughly within the medical profession. It followed that he was interested in the developing sciences of neuroanatomy and neurophysiology, and thought these studies should encompass the mind and constitute the science of mental physiology. These ideas corresponded with those of the English school of Spencer, Bain, and J. S. Mill. ${ }^{83}$ The situation was further complicated by Laycock's interest in the new evolutionary theories, and his suggestion that the psychology of animals could be studied in relation to the evolution of the nervous system. ${ }^{84}$ Despite these many interests, Laycock stood directly within the Scottish tradition with which we are familiar. He was greatly impressed by Hamilton's doctrine of subconscious mental activity, and incorporated it into his thought unchanged, quoting much of Hamilton verbatim..$^{85}$ Descartes' belief in perpertual consciousness, ${ }^{86}$ Leibnitz's emphasis upon the obscure perceptions, ${ }^{87}$ and the Scottish psychology of dreaming and somnambulism $^{88}$ were also preserved in Laycock's writing. Even more remarkable is the direct adoption of Hamilton's new interpretation of association psychology. Laycock went so far as to claim that Hamilton's most impressive argument for the subconscious mind derived from his observation of mental associations that existed below the level of awareness. ${ }^{89}$

The two Scottish physicians maintained great authority and influence, and as a result associationism became intimately linked to the notion of subconscious mental activity. It was in this highly transformed context that the simple psychology of Hume and Hartley was presented to the medical psychologists of the late nineteenth century.

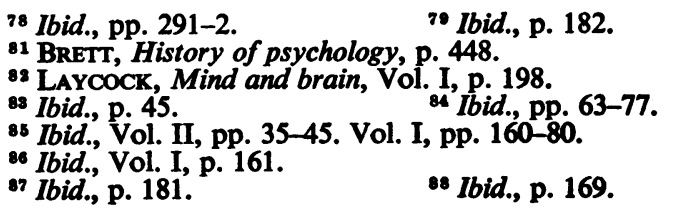

1 BRETT, History of psychology, p. 448.

83 Ibid., p. 45.

86 Ibid., Vol. I, p. 161

87 Ibid., p. 181 .

${ }^{88}$ Ibid., p. 169.

so Ibid., p. 189.

so Ibid., p. 178. 


\section{The History of Associationism}

The passive processes of mind implicit in the thought of these early associationists were now spoken of as subconscious mental functions; and the active faculties of mind that Reid had borrowed from Aquinas, were now spoken of in terms of the German concept of Ego.

\section{CONCLUSIONS}

Medical psychology preserved the classical faculties of Aristotle, Galen, and Thomas Aquinas unaltered until the beginning of the eighteenth century. Since this psychology was closely related to the scholastic concept of the soul, it was held as dogma until challenged by the empirical philosophy of Locke, Hume and Hartley. In medicine the faculties were only partially rejected. The old psychology was still employed by Willis, Rowley, and Crichton. Arnold and Haslam, on the other hand, forcefully opposed the standard approach, and maintained that the facilities had no place in the new empiricism in medicine.

Associationism came to play a dominant role in the psychiatric thought of the eighteenth century. Sensations, or their resulting ideas, were attracted and combined as though governed by mechanical laws. It was appropriate that the century which considered sensation and association the basis of rational thought, also considered these processes basic to proper nervous and mental functioning. Disorders of the mind were viewed as diseases of the sensing and associating mechanisms. Since both of these processes were controlled by physical, biological factors, it followed that insanity was an organic disease of the brain or the nerves, for the Zeitgeist demanded that the new empirical method be applied to tangible, observable matter. In this way the impact of Newton upon the philosophy and science of the century pervaded the medical world as well.

The early nineteenth-century physicians rejected the psychology of their predecessors in favour of a more practical and scientific approach, although certain Scottish philosophers of the period remained interested in the associationism of the previous century and incorporated it directly into their scholastic view of the faculties. In the simplest terms, they gave the process of mental associations the status of a special faculty of mind. In this way the two traditions we have traced merged in the nineteenth century Scottish school. Such a reconciliation could not easily occur and only became possible by dividing the associating process into its active and passive components. This basic division proved to be more than a mere academic distinction. It was gradually extended until the entire mental apparatus was split. The original terminology of Stewart and Brown was based upon the eighteenth-century concepts of activity and passivity. William Hamilton, and his disciple Thomas Laycock, finally broke into the psychology of the preceding century as they reworked the Scottish philosophy around the German concept of consciousness. In this way the active faculties and the passive associations gradually evolved into the psychiatric concepts of the late nineteenth century. 


\section{R. Hoeldtke}

\section{BIBLIOGRAPHY}

AвrRCrombie, John, Inquiries Concerning the Intellectual Powers and Investigation of Truth, Edinburgh, Waugh and Innes, 1832.

AlLEN, M., Essay on Classification of the Insane, London, John Taylor, 1833.

ARnold, Thomas, Observations on the Nature, Kinds, Causes and Prevention of Insanity, Lunacy, or Madness, 2 vols., London, G. Ireland, 1782-1786.

Batrie, William, A Treatise on Madness, London, 1758.

BROWN, ThOMAs, Lectures on the Philosophy of the Human Mind, 4 vols., Edinburgh, James Ballantyne, 1820.

Burrows, Grorge Man, Commentaries on the Causes, Forms, Symptoms and Treatment, Moral, Medical of Insanity, London, 1828.

Cheyne, Grorge, The English Malady; or a Treatise of Nervous Diseases of All Kinds, London, S. Powell, 1733.

ChieYni, Grorge, The Natural Method of Curing Diseases of the Body and the Disorders of the Mind Depending on the Body, London, 1753.

CoNolly, JoHN, Indications of Insanity, ed. Hunter and MacAlpine, London, Dawsons of Pall Mall, 1964.

Cox, J. M., Practical Observations on Insanity, London, E. Bryan, 1813.

Crichton, AlBXANDER, An Inquiry into the Nature and Origin of Mental Derangement, 2 vols., London, 1798.

CrowthiR, BRYAN, Practical Remarks on Insanity; to which is added a Commentary on the Dissection of Brains of Maniacs, London, 1811.

Cullen, Wrilam, Materia Medica, 2 vols., Philadelphia, Matthew Carey, 1808.

Cullen, Winliam, Practice of Physic, 2 vols., Philadelphia, Thomas Dobson, 1816.

DarWIN, ERAsmus, Zoonomia or the Laws of Organic Life, 4 vols., London, T. Bentley, 1801.

FALCONER, WIILIAM, Dissertation on the Infuence of the Passions upon the Disorders of the Body, London, 1796.

GrEgory, JOHN, A Comparative View of the State and Faculties of Man with Those of the Animal World, London, 1774.

Hamilton, Winliam, Lectures on Metaphysics and Logic, 4 vols., ed. by Monsel and Vetch, Edinburgh and London, William Blackwood and Sons, 1860.

HARPER, ANDREW, A Treatise on the Real Cause and Cure of Insanity, London, J. Walker, 1789.

Hartuey, David, Observations on Man, His Frame, His Duty, and His Expectations, 2 vols., London, W. Eyres, 1801.

HASLAM, JoHn, Observations on Insanity, London, 1798.

HAstam, JoHn, Observations on Madness and Melancholy, London, Callow, 1809.

Haslam, JoHn, Sound Mind, London, Longman, Hurst, Rees, Orme, \& Brown, 1819.

HuMr, DAVID, Treatise on Human Nature, 2 vols., New York, E. P. Dutton, 1959.

KNIGHT, P. S., Observations on the Causes, Symptoms and Treatment of Derangement of the Mind, London, Longman, Rees, Orme, Brown \& Greene, 1827.

LAWRENCE, SIR Winliam, Lectures on Physiology. Zoology, and Natural History of Man, delivered at the Royal College of Surgeons, London, 1819.

LAYCOCK, Thomas, Mind and Brain, 2 vols., Edinburgh, Sutherland and Knox, 1860.

LOCKE, JoHn, An Essay Concerning Human Understanding, Dublin, Brett Smith, 1816.

MAYO, THOMAs, Remarks on Insanity; founded on the practice of John Mayo, M.D., London, 1817.

Neville, Winliam, On Insanity, Its Nature, Causes and Cure, London, 1836.

Perry, Charles, A Mechanical Account and Explication of the Hysteric Passion, London, 1755.

Prichard, James Cowles, Insanity, London, Sherwood, Gilbert \& Piper, 1835.

Prichard, James Cowles, A Review of the Doctrine of a Vital Principle, London, 1829.

PURCELl, John, A Treatise of Vapours or Hysterie Fits, London, 1707.

REID, Thomas, Essay on the Intellectual Powers of Man, Boston, Philips, Sampson \& Co., 1854. 
The History of Associationism

SEYMOUR, EDWARD J., Observations on the Medical Treatment of Insanity, London, Longman, Rees, Orme \& Brown, 1817.

SPURZHEIM, J., Observations on the Deranged Manifestations of the Mind, or Insanity, London, Baldwin, Cradock, and Joy, 1817.

SpUrzhem, J., A View of the Philosophical Principles of Phrenology, London, 1825.

Strwart, Dugald, Works, 11 vols., edited by Sir William Hart, Edinburgh, Thomas Constable, 1854.

SYER, J., Dissertations on the Features and Treatment of Insanity, London, 1827.

UwINs, DAVID, A Treatise on those Disorders of the Brain and Nervous System, which are usually called Mental, London, Renshaw \& Rush, 1833.

Willis, Francis, Treatise on Mental Derangement, London, Longman, Hurst, Rees, Orme \& Brown, 1823.

\section{SECONDARY SOURCES}

Brett, Grorge, History of Psychology, ed. and rev. by R. Peters, New York, Macmillan, 1962.

Hart, Thomas, The Thomistic Concept of Mental Faculty, Washington, Catholic University of America, 1930.

Hunter, R., and MACAlPINE, I., Three Hundred Years of Psychiatry, London, Oxford University Press, 1963.

LeIGH, DENIS, The Historical Development of British Psychiatry, vol. 1, New York, Pergamon Press, 1961.

Warren, Howard, A History of Associationism, New York, Scribner, 1921.

Whyte, LANCELot Law, The Unconscious Before Freud, London, Bradford, Dukes, 1960.

ZnBORG, Gregory, History of Medical Psychology, New York, W. W. Norton, 1941. 